\title{
Branding Goals and Strategies at International Auto Shows
}

\author{
Wondwesen Tafesse ${ }^{1}$, Jahan Narui ${ }^{1} \&$ Tor Korneliussen ${ }^{1}$ \\ ${ }^{1}$ Bodø Graduate School of Business, The University of Nordland, Bodø, Norway \\ Correspondce: Wondwesen Tafesse, Bodø Graduate School of Business, The University of Nordland, Bodø \\ 8049, Norway. Tel: 47-7551-7627. E-mail: wondwesen.tafesse.eshetie@uin.no
}

$\begin{array}{lc}\text { Received: April 28, } 2014 & \text { Accepted: May 13, } 2014 \quad \text { Online Published: July 28, } 2014 \\ \text { doi:10.5539/ijms.v6n4p23 } & \text { URL: http://dx.doi.org/10.5539/ijms.v6n4p23 }\end{array}$

\begin{abstract}
This study investigates the branding goals and strategies of four globally renowned car companies at the 2013 edition of the Geneva Motor Show. The study collected and analyzed data on the branding activities of the four companies from a variety of sources. The findings indicate that the four car companies utilized the Geneva Motor Show to pursue two types of strategic branding goals: brand image reinforcement and brand image renewal. The findings further reveal that the car companies applied a three stage brand building strategy based on a temporal division of the Geneva Motor Show into pre-, at- and post-show stages, pursuing distinct brand building strategies during each stage such as publicity, experiential branding, brand advertising and sales promotion. The findings contribute to the literature by shedding light on an important yet little researched brand building platform in the automotive industry.
\end{abstract}

Keywords: auto shows, automotive industry, branding goals, branding strategy, car companies, experiential branding, motor shows

\section{Introduction}

As manufacturing technologies converge, car companies find it increasingly difficult to differentiate themselves purely on functional features (Chatterjee, Jauchius, Kaas, \& Satpathy, 2002). One major consequence of this technological convergence is car companies' growing reliance on branding as a source of differentiation (Hirsh, Hedlund, \& Scweizer, 2003; Tay, 2003). Car companies engage in brand building efforts in order to make their cars attractive for consumers and elicit positive behavioral outcomes from them such as purchase preferences and brand loyalty (Aaker, 1997; Park, Maclnnis, Priester, Eisingerich, \& Iacobucci, 2010). The importance of branding to car companies is evident in the amount of money invested in branding efforts. According to Chatterjee et al. (2002), for instance, the US automotive industry spent more than $\$ 50$ billion on branding efforts in 2000 alone.

International auto shows, which constitute the main focus of the current study, are important, yet little researched, brand building platforms in the automotive industry (Narui, 2013). Several globally renowned auto shows take place every year worldwide. Some of the best known names include the Frankfurt Motor Show, the Geneva Motor Show, the Detroit Auto Show, the Paris Motor Show, and Auto China. These are large scale events attracting massive industry, consumer and media attention globally (Forbes, 2013; Narui, 2013). Our primary thrust in this article is that international auto shows, like those mentioned above, offer car companies great opportunities to build and enhance their brand image on a global scale, as evidenced in the following three defining features.

First, international auto shows attract a large number of national and international journalists who regularly write about the automotive industry (Kaydo, 2013; Leblanc, 2013). These journalists extensively cover the car brands at auto shows, extending their reach far beyond the immediate auto show audience. Second, international auto shows bring together hundreds of thousands of consumers and car enthusiasts at one place for a specified period of time (Narui, 2013). This means, car companies are able to reach a sizable amount of consumers cost effectively and in a streamlined fashion. Third, international auto shows present unique experiential opportunities for creating rich and memorable consumer experiences (Forbes, 2013; Kaydo, 2013). Car companies can combine attractive stand designs with new car products and innovations to give consumers multisensory experiences. 
Building on the above points, our aim is to find out how exactly car companies are utilizing international auto shows for branding purposes. More specifically, we investigate the following two research questions:

1) What sort of branding goals do car companies pursue at international auto shows? And;

2) What sort of branding strategies do car companies implement at international auto shows?

To answer these research questions, we employed a qualitative approach and studied the branding activities of four globally renowned car companies that participated at the 2013 edition of the Geneva Motor Show (GMS). We collected data through in-depth interviews with senior marketing and PR managers of the four car companies. We also gathered data through direct observations of the activities of the four car companies and a further exploration of relevant secondary data sources. Interpretive analyses of these data indicate that the four car companies utilized the GMS to pursue two types of strategic branding goals: brand image reinforcement and brand image renewal. The analyses further revealed that the four car companies implemented a three stage brand building strategy by temporally dividing the GMS into pre-, at- and post-show stages and applying distinct brand building strategies during each stage. The details of these findings expose the rich potential of international auto shows for building strong automotive brands. The remainder of the paper is structured into four sections. Section two synthesizes the literature to map out car companies' brand building efforts against car buyers' behaviors and to expound on the branding potential of international auto shows. Section three describes the methodology of the study. Section four reports the findings of the study. Section five concludes the paper by drawing attention to its theoretical and practical implications.

\section{Synthesis of the Literature}

\subsection{The Importance of Branding in the Automotive Industry}

The automotive industry is at the forefront of building strong brands and leveraging these for competitive ends. Indeed, branding is so critical in the automotive industry that car companies usually hire multiple brand managers as well as external brand consultants to continually assess the health of their brands (Green, 2010). Moreover, car companies spend significant sums of money every year on different brand building efforts (Chatterjee et al., 2002). The question, therefore, is not about whether brand building is important for car companies but about why brand building occupies such a central place in the overall strategy of car companies. Several possible answers related to car buyers' behavior can be synthesized.

The first reason is that car purchases represent significant investments for car buyers (Haddock \& Tse, 2007). Consequently, car buyers are analytical in their car buying decisions, carefully assessing alternative offers against a set of relevant attributes like price, safety and reliability (Hirsh et al., 2003). Due to the proliferation of technologically convergent car products in the market place, however, car buyers are increasingly faced with a vast array of similar alternatives (Tay, 2003). This, combined with car buyers' analytical evaluation of alternatives, calls for the existence of a sharp differentiation strategy in the market place (Hirsh et al., 2003; Tay, 2003). This is where brands, with their unique symbolic and imagery functions, come into play (Fournier, 1998; Keller, 2003). Unless alternative offers are clearly differentiated in the market place by means of brands, consumers will have difficulty isolating one car make from another, obscuring their present as well as future decisions.

The second reason, also related to car buyers' behavior, has to do with consumers' lifestyle and emotional connections with cars (Haddock \& Tse, 2007; McAlexander, Schouten, \& Koeing, 2002). Consumers strongly identify themselves with the cars they own (McAlexander et al., 2002). Certain consumers prefer certain car brands so that they can make lifestyle statements to others and, in the process, build and reinforce their self-image (Haddock \& Tse, 2007; Schouten \& McAlexander, 1995). Furthermore, consumers are emotionally connected to their cars, displaying a range of emotions toward them including, but not limited to, affection, excitement and intimacy (Fournier, 1998; Sheller, 2004; Urry, 2006). Car companies cultivate these lifestyle and emotional connections to position and differentiate their brands (Hirsh et al., 2003). To this end, they deploy a range of techniques like usage imagery, personification, associations and multisensory experiences (Aaker, 1997; Park et al., 2010; Schouten \& McAlexander, 1995).

The third reason has to do with a culturally evolved society which views cars less and less as a means of transportation alone (Urry, 2006; Sheller, 2004). Cars are increasingly viewed as cultural artifacts. In fact, powerful subcultures anchored in the celebration of car brands have been in existence for some time now (McAlexander et al., 2002; Sheller, 2004; Urry, 2006). Examples of these subcultures include car collection, car styling, car modification, car racing and car brand communities (McAlexander et al., 2002; Schouten \& McAlexander, 1995). The growing level of cultural symbolism attached to cars, supplies additional impetus to 
car companies' drive to build strong brands. For instance, car companies sponsor and endorse various cultural events believed to enhance their brand image (Levin, Joiner, \& Cameron, 2001; Schouten, McAlexander, \& Koeing, 2007). They also support and facilitate different leisure activities organized through brand communities (McAlexander et al., 2002).

In summary, consumers' need for differentiation, identity expressiveness and cultural symbolism explain why brands and branding efforts occupy a central place in the overall strategy of car companies. By creating strong lifestyle, emotional and cultural bonds with customers, strong car brands can easily influence crucial aspects of consumer behavior including purchase preferences, brand loyalty, brand advocacy and the willingness to pay premium prices (Aaker, 1996; Ailawadi, Lehmann, \& Neslin, 2003; Park et al., 2010).

\subsection{The Branding Potential of International Auto Shows}

Earlier, we briefly highlighted three fundamental features of international auto shows that have implications for branding. Here, we revisit that discussion to throw more light on the brand building potential of international auto shows.

The ability to attract a large number of national and international journalists, and the resulting publicity coverage, is the first defining feature of international auto shows. For instance, the 2013 edition of the GMS attracted about 10,000 local and international journalists. To cater to such an influx of journalists, organizers of international auto shows arrange exclusive press days a day or two before the main event (Narui, 2013). On these dates, journalists acquire exclusive access to the show floor where they closely examine the cars on display and attend press conferences (Kaydo, 2013; Leblanc, 2013). Through these activities, journalists gather pertinent information about the cars on display and convert these details into reviews and news stories and publish or broadcast them to their respective audiences (Narui, 2013). This extensive publicity has enormous consequences for the brands. First, such publicities create brand awareness on a global scale by reaching hundreds of thousands of people who were not directly in attendance at the shows. Second, the publicities outlive the auto shows themselves. The reviews and news stories will be accessible long after the auto shows are closed. Finally, the publicities enjoy higher source credibility because journalists are seen as independent professionals, separate from the car companies. This acts to strengthen the authenticity of brand messages communicated at international auto shows.

The second defining feature of international auto shows is the massive number of national and international consumers they attract (Narui, 2013). For instance, the 2013 edition of the GMS was attended by more than 700,000 local and international consumers for the eleven days it stayed open to the public. The attendance figures for other international auto shows are comparable to the figure cited above, suggesting that brands exhibiting at international auto shows can reach a vast number of national and international consumers in a streamlined and cost effective way. What is more is that consumers' visits to international auto shows are self-initiated (Tafesse \& Korneliussen, 2012b; Tanner, 2002). Most of the visitors arrive at international auto shows on their own term. This helps make brandng efforts at international auto shows effective because they would be directed toward an already enthusiastic and receptive audience. This fundamental aspect is what sets international auto shows apart from other forms of branding efforts such as mass advertising. In mass advertising, it is the marketer who makes a deliberate effort to reach consumers and because of this, mass advertising can be perceived as intrusive by consumers, reducing its ultimate effectiveness (Keller, 2009; Nowak \& Phelps, 1994). International auto shows are not beset by intrusiveness.

The third defining feature of international auto shows is the experiential richness that they afford (Forbes, 2013; Kaydo, 2013). This experiential richness originates from three sources: the cars on display, the stimulating stand designs and the specialized stand representatives. These three factors operate in unison to create rich and multisensory consumer experiences. Consumers' unrestricted access to the cars on display represents a prime source of experience at international auto shows. Consumers can closely explore, touch, smell and get a feeling for the cars. The stimulating stand design is another prime source of consumer experience. Stands deploy creative designs and are equipped with attractive display platforms, dynamic light works and sound systems together with large display screens (Forbes, 2013; Kaydo, 2013). Some stands possess additional attractions such as simulated driving devices and touch screen computers from which consumers can access on-demand information. Finally consumers can enhance their experience by interacting with the specialized stand representatives. These three factors combine to render international auto shows useful for experientially branding purposes. This multisensory rendering of car brands result in favorable brand attitudes and deeper brand connections (Borghini, Diamond, Kozinets, McGrath, Muniz, \& Sherry, 2009; Dolbec \& Chebat, 2013; Schouten et al., 2007). 


\section{Research Methodology}

In order to answer the two research questions that motivated this study, we employed a qualitative approach. Qualitative study, with its emphasis on in-depth and context-dependent enquiry, is appropriate for the current research, as it is exploratory in nature (Flyvbjerg, 2006; Yin, 2009). We studied the brand building practices of four conveniently selected car companies that participated at the $83^{\text {rd }}$ edition of the GMS held from March 5 to March 17, 2013. The $83^{\text {rd }}$ edition of the GMS was attended by more than 170 car companies, 700,000 consumers, and 10,000 journalists, drawn from various countries. These figures make the GMS one of the top five motor shows in the world (Narui, 2013). Initially, we approached more car companies to be part of our study. However, some of the contacted companies refused cooperation citing busy schedules. Our empirical investigation was, therefore, built on observations of four conveniently selected car companies.

The four companies are globally renowned car brands, two of them based in West Europe and the remaining two in East Asia. We used pseudonyms to disguise the corporate identity of the four car companies. Empirical data was collected in multiple ways. First, we interviewed senior managers from each of the four companies. The interviewed managers hold such positions as Marketing Manager, Communications Manager, Marketing \& PR Manager and PR Assistant. The choice of informants was in line with the latest research showing that functional managers are fully informed about their companies' trade show campaigns (Tafesse \& Korneliussen, 2012a). The interviews took place inside the companies' stands during the press days of the GMS, and were in-depth, each lasting about an hour, and all were audio taped. In addition to the interviews, we were given full access to the display areas of all four companies. We carefully observed the spatial arrangement of the display areas and recorded our observation using extensive field notes.

In addition to these primary data sources, we also explored secondary data sources. This task was carried out continuously for weeks after the GMS had closed, and involved exploring a diverse array of secondary information sources such as publications from organizers of the GMS, official corporate press releases from the four selected car companies, Youtube videos and on-line news stories. The resulting collection of information regarding the brand building goals, strategies and activities of the four car companies were interpreted and triangulated to answer the two research questions that motivated our study. The results of these analyses are discussed at length in the subsequent section.

\section{Findings}

\subsection{Branding Goals at the GMS}

Representatives of all four companies spoke very positively about the importance of the GMS in terms of pursuing strategic branding goals. Although the specific branding goals pursued differed from one company to another, we were able to find some common patterns. Underlying the branding goals of all four car companies was the desire to convey a positive brand image. While two of the companies were intent on reinforcing their existing brand image, the other two companies were working toward a renewed brand image. We, therefore, separated the strategic branding goals pursued by the four companies into two: brand image reinforcement and brand image renewal.

The first strategic branding goal, brand image reinforcement, reflected a strong desire on the part of the car companies to maintain and strengthen awareness about their existing brand image. This goal involved little change in terms of communicable brand messages, associations and positioning. Car companies that were keen on reinforcing their brand image chose to do so simply by highlighting recognizable features of their car design and technologies. They did not introduce radical innovations, only incremental technological enhancements to their existing line of products. As the following interview excerpts indicate, the branding goals of Alpha Europe and Alpha Asia were designed with brand image reinforcement in mind:

"We have a couple of things we want to put forward at this show. The first is our unique design. Although many people recognize our design quite well, we want to further strengthen that awareness. Then there is the issue of technology, which for us has always been about safety and the environment. So we'd like to highlight the safety and green aspects of our cars too." PR Assistant, Alpha Europe.

"Well, our major branding goal is to increase awareness about our brand image which is built on a class leading technology and innovation. It is important to imagine the Geneva Motor Show as a large show room where we show our leading technology and innovation and this obviously is going to promote our brand image even more." Marketing Manager, Alpha Asia.

The second strategic branding goal, brand image renewal, reflected a strong desire on the part of the car companies to renew their existing brand image. This goal emphasized conveying altered or new brand messages, 
associations and ideas. The companies that were working toward a renewed brand image emphasized introducing new and innovative lines of products that were consistent with the renewed brand image and positioning that they would like to create. They deployed their new car products and technological innovations to cement awareness about their renewed brand image. The branding goals of Beta Europe and Beta Asia, as the following interview excerpts document, were aimed at brand image renewal:

"Our main objective during this show is to present our new car collections. This show will be particularly important because we'll premier one of our models to Europe... We'd also like to change our brand image and become more appealing to young customers. We've been working really hard on our cars' designs to achieve that modern look, which is really important to attract young customers. But we also understand that it's going to take time. Changing your brand image can't happen overnight”. Marketing Manager, Beta Europe

"For us, branding goals always depend on the theme of the show. This time, our goals are about two related things. The first one is to change consumers' perceptions about our brand. Consumers still think of our brand as having less quality than European brands. This isn't true, as proven by external research companies like JD Power. So we are determined to change that. Our second goal, which is quite thrilling for us, is to introduce the performance version to one of our models and a newly developed B-segment concept car". Marketing and PR Manager, Beta Asia

Thus, the four car companies utilized the GMS to pursue strategic branding goals that could be distinguished along two lines: brand image reinforcement and brand image renewal. Brand image reinforcement was focused on strengthening awareness about existing brand images and it relied on familiar brand messages and associations together with existing line of products. On the contrary, brand image renewal was focused on altering existing brand images and it relied on altered or new brand messages and associations augmented by new product introductions that are consistent with the altered brand image that the car companies would like to cement.

\subsection{Branding Strategies at the GMS}

The four car companies followed a three stage branding approach to achieve their branding goals. They temporally divided the GMS into pre-, at- and post-show stages, with the pre-show stage representing the planning and publicity phase before the main event; the at-show stage, the live, exposition phase during the main event; and the post-show stage, the follow-up phase after the main event. The companies implemented different brand building strategies for each stage. For analytic purposes, these strategies were classified into two priority levels: primary and secondary. Those brand building strategies that were afforded greater attention and resources were classified as primary and those that were afforded lesser attention and resources were classified as secondary. The branding strategies of the four companies, divided along three temporal stages and two priority levels, are summarized in Table 1.

Table 1. Summary of branding strategies at international auto shows

\begin{tabular}{llll}
\hline & Temporal stages & & \\
\cline { 2 - 4 } Priority levels & Pre-show & At-Show & Post-Show \\
\hline Primary & Publicity & Experiential branding & Sales promotion \\
Secondary & Brand advertising & Brand advertising & Publicity \\
\hline
\end{tabular}

\subsubsection{Pre-Show Stage}

\subsubsection{Primary Strategy: Publicity}

During the pre-show stage of the GMS, all four car companies pursued a brand building strategy based primarily on generating publicity for their respective brands. Publicity consists of a variety of communications such as editorial contents, news articles and technical reviews which are produced by independent media organizations about company brands, products and services (Marken, 1987; Wang \& Nelson, 2006). Like advertising, publicity creates brand awareness, changes consumers' attitude toward brands and influences behavior. Unlike advertising, however, publicity enjoys greater credibility as it is perceived by consumers as existing to inform and not to sell (Stammerjohan, Wood, Chang, \& Thorson, 2005; Wang \& Nelson, 2006). The effect of publicity on consumers' brand awareness and attitude can be positive or negative depending on its content and framing (Stammerjohan et al., 2005). 
The publicity strategies of all four companies during the pre-show stage were aimed at purposively and exclusively introducing their products and innovations to journalists. In so doing, car companies would hope to generate positive editorials, reviews and news articles about their brands. Such publicity coverage would of course amplify and reinforce the companies' brand messages. To this end, the four car companies reported employing a variety of pre-show publicity tactics. For instance, all four companies employed press releases. The press releases, targeted exclusively at journalists and dispatched prior to the opening of the GMS, provided an overview of the overall exhibit program of the car companies as well as the technical details and specifications of the cars on display. The Communications Manager at Beta Europe explained how they deployed press releases as follows:

"Our press release gives journalists information about the technical details and specifications of our cars. We've two types of press releases. The first one is done at the local level, the other one is done globally, at the corporate level. We also maintain an on-line newsroom where images, texts and contents can be downloaded. We do all this stuff to give journalists all the details they need to give us good publicity coverage".

Similarly, all four companies arranged exclusive, elaborate and carefully choreographed press conferences for journalists during the press days. The press conferences featured a coterie of senior corporate executives from the car companies. The companies used these events to present their cars to the journalists, talk about their major corporate achievements in the recent past and offer a glimpse of where they want to go in the future. Furthermore, some of the companies utilized digital tools including corporate websites, blogs and social networking sites to generate pre-show publicity. This was pretty much the case for Beta Asia which relied on a heavily digitalized pre-show publicity approach:

"As always we've a pre-established schedule to generate pre-show publicity. This includes press releases, what we call "the day before the show" media lounge with 300 to 400 journalists and different digital tools such as our website, blogs and facebook. Actually, we always live-stream our press conferences on our corporate website. We also use the internet to share teaser sketches of our new cars to the media". Marketing \& PR Manager, Beta Asia.

On top of the aforementioned pre-show publicity tactics, additional tools specific to some of the car companies were applied. For instance, one car company arranged a pre-show visit to a production facility located in Switzerland in order to give journalists an intimate and firsthand account of the cars to be displayed at the GMS. Another company arranged a business lunch during one of the press days of the GMS to socialize with journalists. The purpose behind all these pre-show publicity efforts was to get the journalists motivated, entertained and informed so that they could effectively publicize the companies' brands.

\subsubsection{Secondary Strategy: Brand Advertising}

Brand advertising refers to marketer initiated communications with favorable brand claims which are designed for end consumers (Keller, 2009; Nowak \& Phelps, 1994). Brand advertising is about imparting core brand promises, values and messages as well as functional attributes to consumers using a variety of tools such as mass advertising, direct mail, brochures, emails, websites and social networking sites, among others (Carlson, Grove, \& Dorsch, 2003; Tafesse \& Korneliussen, 2013). As noted earlier, the primary brand building strategy of all four companies during the pre-show stage was publicity. The companies' attention and efforts were largely about generating strong publicity for their respective brands, causing them to pursue brand advertising halfheartedly, with limited scope and resources. This led to the profiling of brand advertising as secondary level brand building strategy.

The secondary role of brand advertising during the pre-show stage is evident in the fact that only two of the four companies reported implementing some amount of brand advertising, while the remaining two companies had no organized pre-show brand advertising to speak of. When applied during the pre-show stage, brand advertising efforts were applied largely to invite and remind consumers to visit the companies' stands at the GMS. The invitations and reminders were sent through direct mails and emails. Car companies' reluctance about deploying brand advertising during the pre-show stage might have stemmed from the expectation that the extensive pre-show promotional campaigns done by the organizer of the GMS could generate enough visitor traffic for them. It is not uncommon for exhibitors to piggyback on the pre-show promotional campaigns of organizers for drawing traffic to their stands (Gopalakrishna \& Lilien, 2012; Tafesse, 2014). 


\subsubsection{At-show Stage}

\subsubsection{Primary Strategy: Experiential Branding}

All four companies were acutely aware of the brand building potential of consumer experiences. They acknowledged that facilitating rich experiences would allow consumers to form deeper connections with their brands. It came as little surprising, thus, when all four companies tried to put experiential branding to powerful effects during the at-show stage, prompting us to profile experiential branding as the primary brand building strategy of the at-show stage. Conceptually, experiential branding involves embedding brands with unique objects, people and events in order to render the brands accessible to consumers through their senses and bodies (Borghini et al., 2009; Schouten et al., 2007). Such multisensory rendering of brands allow consumers to interact with the brands both at the functional and emotional level (Borghini et al., 2009; Schouten et al., 2007). The ultimate goal of experiential branding is establishing deeper and meaningful connections between consumers and brands.

Our interview material, direct observation, and secondary data sources indicate that the car companies designed and incorporated different elements into their stands in order to make their brands experientially accessible to consumers. For example, consumers were offered unrestricted access to the cars on display in all four stands such that they could closely explore, touch and get a feeling for them. Moreover, all four stands were designed and spatially arranged in an attractive way. They were outfitted with attractive display platforms, huge display screens and dynamic light and sound systems. The careful arrangement of the stands in terms of design and furnishing could easily evoke consumers' senses of sight, sound, touch and smell in relation to the focal brands. Plus, in all four stands, consumers were able to talk to specialized stand representatives and browse interactive touch screen devices installed beside the displayed cars. This allowed consumers to learn about the functional benefits of the car brands in a more personalized manner.

In addition to the aforementioned experience-creating efforts, which were all set inside the companies' main stands, three of the four companies (except Alpha Asia) enhanced consumer experiences using exclusive lounges. The lounge areas were separated from the main stands and were utilized to treat loyal and important customers to special amenities such as refreshments, personal attention, entertainment and so forth. The PR Assistant at Alpha Europe explained the importance of their lounge in terms of facilitating consumer experiences:

"As you can see, we have a complete lounge here. It's designed to make our customers feel welcomed and at home. We sit down with them in here; have coffee and exchange ideas and opinions. Our intention is to let them feel our brand in a more relaxed environment. You can't do this inside the main stand which is kind of busy all the time".

\subsubsection{Secondary Strategy: Brand Advertising}

As noted earlier, brand advertising refers to marketer initiated communications with favorable brand claims which are designed for end consumers (Keller, 2009; Nowak \& Phelps, 1994). As in the pre-show stage, brand advertising assumed a secondary role during the at-show stage. The difference is, however, during the at-show stage brand advertising assumed a secondary role deliberately. The car companies did not want to overload consumers with too much brand ads as this might disrupt their involvement with the multisensory experiences facilitated inside the display stands. The companies seemed to believe that brand advertising and experiential branding do not go hand in hand and were willing to trade more undisrupted consumer experiences for less brand advertising exposures. On this issue, the Communications Manager at Beta Europe remarked the following:

We don't distribute brochures and price lists here for customers. Our main focus during the show is to collect their contact addresses. And then, after the show, we'll send them all the necessary information through their addresses.

Somewhat surprisingly, the PR Assistant at Alpha Europe expressed an almost identical view point:

"During the show, we work hard to get the addresses of visitors, but we don't generally distribute brochures here. We start contacting our customers after we finish our work here and get back to our offices. So basically if you visit us today, you can expect to hear from us within a handful of days".

Alpha Asia had an even more laid-back approach about the idea of brand advertising during the show:

"To be honest, we aren't well prepared for this show in terms of brand ads. We received some materials from the corporate office a couple of weeks ago. We translated them and we'll use them at the show. We really got nothing special for this show" Marketing Manager, Alpha Asia. 
Generally, the companies adopted a cautious approach of doing not too much brand advertising at the show. They deliberately minimized the scope of their brand advertising efforts so that consumers could immerse themselves in the complete experience of the cars on display. However, when brand advertising was implemented at the show, print ads were the preferred channels of communication.

\subsubsection{Post-show Stage}

\subsubsection{Primary Strategy: Sales Promotion}

We observed that the branding strategies of the four car companies during the post-show stage have some similarities with that of the pre-show stage. For instance, in both stages, publicity was important. However, during the post-show stage, sales promotion took center stage with primary priority, whereas publicity was reduced to secondary priority. Across all four companies, we found that branding efforts during the post-show stage were strongly sales promotion oriented. The companies were particularly keen to close on the sales leads solicited during previous stages. To this end, they, or their dealer networks, contacted sales leads and provided them with sales oriented information such as price lists, promotional offers and proposals for test drives in order to induce them into buying their car products. Here is how the Marketing Manager at Alpha Asia explained their follow-up strategy:

"Every customer who requested brochure will be contacted after the show, not by importers but by local dealers. We inform our local dealers about those customers who requested brochures from us. The dealers will then contact them by phone or email and give them information and maybe propose them a test drive".

Likewise, Beta Europe pursued promotional focused brand advertising during the post-show stage:

"We keep our media campaigns going for customers until the launch dates for our new cars arrive. At the same time, we'll follow up our leads and send them brochures and price lists. Then, prior to the launch date, you'll invite them over for a test drive". Communications Manager, Beta Europe

Depending on internal policies, the follow-ups were performed either by the car companies themselves or by their dealer networks. Because of the proximity of dealers to local customers, some of the companies encouraged their dealer networks to do the follow-ups. This is what Alpha Europe did:

"After the show, we ask our dealers to follow up the leads that we collected at the show. It's in their interest to do so. They can close more sales. Plus they are the ones closer to the customers not us. They can do a better job of following up the customers than we are able to". PR Assistant, Alpha Europe.

\subsubsection{Secondary Strategy: Publicity}

It is interesting to note that the car companies continued to maintain their contacts with journalists and sought their publicity coverage long after the show had closed. However, the enthusiasm for publicity seemed attenuated, especially in light of the flurry of publicity tactics that pervaded the pre-show stage. The car companies' weakened interest for publicity during the post-show stage was reflected in such phrases as "we do not make a big program out of it" and "these days everyone is doing that". The companies were so preoccupied with maximizing their sales outcome from the GMS that their enthusiasm for publicity appeared significantly lessened. Consequently, we profiled publicity as a secondary branding strategy of the post-show stage.

The car companies were particularly adamant about aligning their post-show publicity coverage with the launch dates of their new production-model cars introduced earlier at the GMS. The companies did not actively mobilize the journalists immediately after the GMS for publicity coverage. They were more strategic and sought to synchronize their post-show publicity efforts with the launch dates of their premiers and new model years. Again, the logic at work here appears to be that of maximizing the sales effect of the GMS through the strategic deployment of post-show publicity. The Communications Manager at Beta Europe shed some light on this approach:

"After the show, we invite journalists for a test drive. But this depends on when our launch dates will be. Although these days everyone is doing that [inviting journalists for a test drive], we still invite journalists to come over and try out our new cars before we launch them in the market".

\section{Discussion and Implications}

\subsection{Discussion}

In this study, we were primarily interested in finding out how car companies were utilizing international auto shows for branding purposes. Consistent with this, we adopted a qualitative approach and examined the branding goals and strategies of four conveniently selected and globally renowned car companies at the 2013 edition of 
the GMS. Our qualitative approach, which combined in-depth interviews, direct observations, and exploration of secondary data sources, generated rich empirical material allowing us to construct a complete picture of the branding goals and strategies of the four case companies. In so doing, we made multiple contributions to the literature.

First, the study developed and extended the perspective in the literature which acknowledges the corporate image building aspect of international trade shows. A series of studies have identified corporate image-building as a core function of international trade show participation (e.g., Hansen, 2004; Lee \& Kim, 2008; Tafesse \& Korneliussen, 2011). Apart from proposing and validating image-building as a core function of international trade show participation however, these studies did not actually explore how companies in practice build their brand images through international trade shows. We made an important contribution to this literature by identifying the specific imaging-building goals and strategies that car companies implemented at international auto shows.

In terms of branding goals, we found two distinct types of strategic branding goals: brand image reinforcement and brand image renewal. The first goal, brand image reinforcement, was aimed at strengthening awareness about an existing brand image, and it relied on familiar brand messages, associations and the showing of existing line of products. The second goal, brand image renewal, was aimed at renewing an existing brand image, and it relied on altered or new brand messages, associations and new product introductions that were consistent with the brand image companies would like to build. In terms of brand building strategies, we found a three stage brand building approach based on a temporal division of the GMS into pre-, at- and post-show stages. Each of these stages supported a variety of brand building strategies such as publicity, experiential branding, brand advertising and sales promotion.

Second, we built an empirical case of experiential branding in action. Our findings demonstrated how car companies, using their stands as a platform, facilitated consumers' experiential involvement with their brands both at the functional and emotional level. We documented how the car companies deployed an interrelated set of experience-creating tactics such as unrestricted access to the displayed cars, specialized stand representatives, and stimulating stand designs incorporating attractive display platforms, huge display screens, dynamic lighting and sound systems, and touch screen devices in order to simultaneously evoke consumers' senses of sight, sound, touch and smell. The attractive exposition combined with car companies' hospitable and open policies rendered the displayed car brands experientially accessible to consumers. Our empirical findings about the experiential branding approach at international auto shows represents a useful addition to the nascent, but growing, body of literature on experiential branding (e.g., Borghini et al., 2009; Dolbec \& Chebat, 2013; Schouten et al., 2007).

Third, we contributed to the branding literature by synthesizing a comprehensive theoretical discussion linking car buyers' behavior with car companies' brand building practices. Drawing on a seminal body of works on consumer-brand relationships (e.g., Aaker, 1997; Fournier, 1998; Park et al., 2010; Schouten et al., 2007; Schouten \& McAlexander, 1995), this discussion explained the branding drive of car companies through the lens of car buyers' behavior. More specifically, the discussion highlighted how consumers' need for differentiation, identity expressiveness and cultural symbolism drive car companies' branding efforts. Furthermore, our theoretical discussion synthesized three defining features of international auto shows that facilitate branding efforts on a global scale: extensive publicity coverage, access to a massive number of consumers and the potential for implementing experiential branding. We hope these bodies of theoretical discussions will serve as a basis for more discussions in this area.

\subsection{Implications}

In this section, we highlight the managerial and research implications of our findings. We start by highlighting the managerial implications which will be followed by the research implications.

The first and most obvious managerial implication to emerge from our study is that international auto shows are indeed useful brand building platforms for car companies. Our findings imply that car companies can utilize international auto shows to pursue strategic branding goals by reinforcing and renewing their existing brand image. To accomplish these branding goals, it is important that car companies temporally divide auto shows into pre-, at-, and post-show stages and set different branding priorities for each stage. In this regard, the four car companies that we studied devoted the pre-show stage primarily for publicity-driven brand building, the at-show stage primarily for experiential-driven brand building and the post-show stage primarily for promotion-driven brand building. This three stage approach appeared particularly effective in terms of setting and achieving primary and secondary level branding priorities. 
Second, we observed that international auto shows are intensely competitive events. Car companies compete for the limited attention of journalists, customers and consumers. This competition is mainly played out in the way stands are set up and how brand building approaches are planned and executed. It is, therefore, important that car companies planning to attend international auto shows develop creative approaches about how to configure their stands and other branding strategies. Creative approaches are essential if car companies are to stand out in the crowd and maximize their visibility. A related issue worth noting is how easily things can go wrong at international auto shows given the scale of the events. What is especially notable is how mistakes at auto shows could directly, and often badly, reflect on the brand images of car companies. It is, therefore, important that car companies be meticulous and strategic in the way they approach international auto shows.

With respect to implications for future research, we have two important issues to highlight. First, being a qualitative study, the current effort is limited in its generalizability. The findings apply only to the extent that the four car companies we studied are considered. Generalizing beyond the four companies would require undertaking large-scale study. Therefore, one important way of contributing to the sparse literature on the branding value of international auto shows would be to undertake a large-scale study involving more car companies. Such efforts could generate generalizable findings that could be applied to a wide spectrum of car companies and auto show contexts. Second, by adapting a causal research design approach, some of the brand building strategies that we identified could be modeled to predict a range of brand outcome variables. For example, brand attitude (Aaker \& Keller, 1990; Spears and Singh, 2004), brand attachment (Park et al., 2010) and brand experience (Brakus, Schmitt, \& Zarantonello, 2009) could be posed as dependent variables, while the brand building strategies we identified, such as publicity coverage, experiential branding, brand advertising and sales promotion could be posed as predictors, and their relationships investigated empirically.

\section{References}

Aaker, D. A. (1996). Measuring brand equity across products and markets. California Management Review, 38(3), 102-120. http://dx.doi.org/10.2307/41165845

Aaker, D. A., \& Keller, K. L. (1990). Consumer evaluations of brand extensions. Journal of Marketing, 54(1), 27-41. http://dx.doi.org/10.2307/1252171

Aaker, J. L. (1997). Dimensions of brand personality. Journal of Marketing Research, 34(3), 347-356. http://dx.doi.org/10.2307/3151897

Ailawadi, K. L., Lehmann, D. R., \& Neslin, S. A. (2003). Revenue premium as an outcome measure of brand equity. Journal of Marketing, 67, 1-17. http://dx.doi.org/10.1509/jmkg.67.4.1.18688

Borghini, S., Diamond, N., Kozinets, R. V., McGrath, M. A., Muniz, A. M., \& Sherry, J. F. (2009). Why are themed brandstores so powerful? Retail brand ideology at American Girl Place. Journal of Retailing, 85(3), 363-375. http://dx.doi.org/10.1016/j.jretai.2009.05.003

Brakus, J. J., Schmitt, B. H., \& Zarantonello, L. (2009). Brand experience: what is it? How is it measured? Does it affect loyalty? Journal of Marketing, 73, 52-68. http://dx.doi.org/10.1509/jmkg.73.3.52

Carlson, L., Grove, S. J., \& Dorsch, M. J. (2003). Services advertising and integrated marketing communications: an empirical examination. Journal of Current Issues and Research in Advertising, 25(2), 69-82. http://dx.doi.org/10.1080/10641734.2003.10505150

Chatterjee, A., Jauchius, M. E., Kaas, H., \& Satpathy, A. (2002). Revving up auto branding. The McKinsey Quarterly, 1, 134-143.

Dolbec, P., \& Chebat, J. (2013). The impact of a flagship vs. a brand store on brand attitude, brand attachment and brand equity. Journal of Retailing. http://dx.doi.org/10.1016/j.jretai.2013.06.003

Flyvbjerg, B. (2006). Five misunderstandings about case-study research. Qualitative Enquiry, 12(2), 219-245. http://dx.doi.org/10.1177/1077800405284363

Forbes. (2013). Detroit auto show booths show biz is back. Retrieved from http://www.forbes.com/sites/jeanhalliday/2013/01/16/detroit-auto-show-booths-show-biz-is-back/

Fournier, S. (1998). Consumers and their brands: developing relationship theory in consumer research. Journal of Consumer Research, 24, 343-373. http://dx.doi.org/10.1086/209515

Gopalakrishna, S., \& Lilien, G. L. (2012). Trade shows in the business marketing communication mix. In G. Lilien \& R. Grewal (Eds.), The Business-to-Business Marketing Handbook (pp. 226-245). Cheltenham: Edward Elgar Press. http://dx.doi.org/10.4337/9781781002445.00022 
Gopalakrishna, S., Roster, C. A., \& Sridhar, S. (2010). An exploratory study of attendee activities at business show. Journal of Business \& Industrial Marketing, 25(4), 241-248. http://dx.doi.org/10.1108/08858621011038199

Green, G. (2010). Why car makers are beholden to the power of the brand. Retrieved from http://www.carmagazine.co.uk/Community/Car-Magazines-Blogs/Gavin-Green-Blog/Why-car-makers -are-beholden-to-the-power-of-the-brand/

Haddock, R., \& Tse, E. (2007). Revving up Chinese automotive brands: challenges and opportunities in Chinese carmakers' quest for lasting value. Booth Allen Hamilton.

Hansen, K. (2004). Measuring performance at trade shows: scale development and validation. Journal of Business Research, 57(1), 1-13. http://dx.doi.org/10.1016/S0148-2963(02)00269-2

Hirsh, E., Hedlund, S., \& Schweizer, M. (2003). Reality is perception: the truth about car brands. Strategy+Business, 32, 1-6.

Kaydo, C. (2013). Six trade show booth trends from the New York auto show. Retrieved from http://www.bizbash.com/6-trade-show-booth-trends-from-the-new-york-auto-show/new-york/story/25712/

Keller, K. L. (2003). Brand synthesis: the multidimensionality of brand knowledge. Journal of Consumer Research, 29(4), 595-600. http://dx.doi.org/10.1086/346254

Keller, K. L. (2009). Building strong brands in a modern marketing communications environment. Journal of Marketing Communications, http://www.tandfonline.com/doi/abs/10.1080/13527260902757530

Leblanc, J. (2013). Why China's auto shows matter? Retrieved from http://www.driving.ca/China+auto+shows+matter/8283683/story.html

Lee, C. H., \& Kim, S. Y. (2008). Differential effects of determinants of multi-dimensions of trade fair performance: By three stage of pre-show, at-show and post-show activities. Industrial Marketing Management, 37, 784-796. http://dx.doi.org/10.1016/j.indmarman.2008.01.006

Levin, A. M., Joiner, C., \& Cameron, G. (2001). The impact of sports sponsorship on consumers' brand attitudes and recall: the case of NASCAR fans. Journal of Current Issues \& Research in Advertising, 23(2), 23-31. http://dx.doi.org/10.1080/10641734.2001.10505118

Marken, G. A. (1987). How to place articles for company or product publicity. Public Relations Quarterly, 32(2), $28-31$.

McAlexander, J. H., Schouten, J. W., \& Koeing, H. F. (2002). Building brand community. Journal of Marketing, 66, 38-54. http://dx.doi.org/10.1509/jmkg.66.1.38.18451

Narui, J. (2013). Branding through trade shows in the automotive industry (Unpublished master's thesis). The University of Nordland, Bodø Graduate School of Business, Bodø, Norway.

Nowak, G. J., \& Phelps, J. (1994). Conceptualizing the integrated marketing communications phenomenon: an examination of its impact on advertising practices and its implications for advertising research. Journal of Current Issues \& Research in Advertising, 16(1), 49-66. http://dx.doi.org/10.1080/10641734.1994.10505012

Park, C. W., Maclnnis, D. J., Priester, J., Eisingerich, A. B., \& Iacobucci, D. (2010). Brand attachment and brand attitude strength: conceptual and empirical differentiation of two critical brand equity drivers. Journal of Marketing, 74, 1-17. http://dx.doi.org/10.1509/jmkg.74.6.1

Schouten, J. W., \& McAlexander, J. H. (1995). Subcultures of consumption: an ethnography the new bikers. Journal of Consumer Research, 22(1), 43-61. http://dx.doi.org/10.1086/209434

Schouten, J. W., McAlexander, J. H., \& Koening, H. F. (2007). Transcendent customer experience and brand community. Journal of the Academy of Marketing Science, 35, 357-368. http://dx.doi.org/10.1007/s11747-007-0034-4

Sheller, M. (2004). Automotive emotions: feeling the cars. Theory, Culture \& Society, 21(4/5), 221-242. http://dx.doi.org/10.1177/0263276404046068

Spears, N., \& Singh, S. N. (2004). Measuring attitude toward the brand and purchase intentions. Journal of

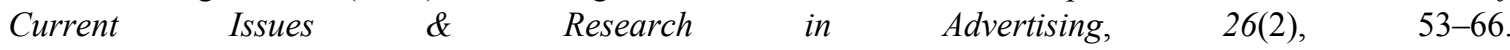
http://dx.doi.org/10.1080/10641734.2004.10505164 
Stammerjohan, C., Wood, C. M., Chang, Y., \& Thorson, E. (2005). An empirical investigation of the interaction between publicity, advertising, and previous brand attitudes and knowledge. Journal of Advertising, 34(4), 55-67. http://dx.doi.org/10.1080/00913367.2005.10639209

Tafesse, W. (2014). Understanding how resource deployment strategies influence trade show organizers performance effectiveness. European Journal of Marketing, 48(5/6), 1-29.

Tafesse, W., \& Korneliussen, T. (2011). The dimensionality of trade show performance in an emerging market. International Journal of Emerging Markets, 6(1), 38-49. http://dx.doi.org/10.1108/17468801111104368

Tafesse, W., \& Korneliussen, T. (2012a). Managing trade show campaigns: why managerial responsibilities matter. Journal of Promotion Management, 18(2), 236-253. http://dx.doi.org/10.1080/10496491.2012.668434

Tafesse, W., \& Korneliussen, T. (2012b). Identifying factors affecting consumers purchase incidence at retail trade shows. Journal of Retailing and Consumer Service, 19(4), 438-444. http://dx.doi.org/10.1016/j.jretconser.2012.04.005

Tafesse, W., \& Korneliussen, T. (2013). Examining the effect of using multiple media tools on the marketing performance of organizations in a trade campaign environment. Journal of Marketing Communications, 19(3), 215-227. http://dx.doi.org/10.1080/13527266.2011.619556

Tanner, J. F. (2002). Levelling the playing field: factors influencing trade show success for small companies. Industrial Marketing Management, 31(3), 229-239. http://dx.doi.org/10.1016/S0019-8501(00)00132-2

Tay, H. K. (2003). Achieving competitive differentiation: the challenge for automakers. Strategy \& Leadership, 31(4), 23-30. http://dx.doi.org/10.1108/10878570310483951

Urry, J. (2006). Inhabiting the car. The Sociological Review, 54(1), 17-31. http://dx.doi.org/10.1111/j.1467-954X.2006.00635.x

Wang, S. A., \& Nelson, R. A. (2006). The effect of identical versus varied advertising and publicity messages on consumer response. Journal of Marketing Communications, 12(2), 109-123. http://dx.doi.org/10.1080/13527260600615626

Yin, R. K. (2009). Case Study Research Design and Methods. Thousand Oaks, California: Sage Publications.

\section{Copyrights}

Copyright for this article is retained by the author(s), with first publication rights granted to the journal.

This is an open-access article distributed under the terms and conditions of the Creative Commons Attribution license (http://creativecommons.org/licenses/by/3.0/). 